\title{
Feeding potential of rangelands in Balochistan-Pakistan: A brief review
}

\author{
Illahi Bakhsh Marghazani ${ }^{*}$, Muhammad Yaseen², Muhammad Afzal², \\ Ihsanullah Kakar ${ }^{1}$ and Sajid Ali Khosa ${ }^{2}$ \\ 1. Faculty of Veterinary and Animal Sciences, Lasbela University of Agriculture, Water \& Marine Sciences, Uthal- \\ Pakistan \\ 2. Livestock and Dairy Development Department, Balochistan-Pakistan \\ *Corresponding author's email: marghazani76@yahoo.com \\ Citation \\ Illahi Bakhsh Marghazani, Muhammad Yaseen, Muhammad Afzal, Ihsanullah Kakar and Sajid Ali Khosa. Feeding \\ potential of rangelands in Balochistan Pakistan: A brief review. Pure and Applied Biology. Vol. 9, Issue 1, pp1184- \\ 1190. http://dx.doi.org/10.19045/bspab.2020.90124
}

\begin{tabular}{llll}
\hline \hline Received: 11/11/2019 & Revised: 16/01/2020 & Accepted: 23/01/2020 & Online First: 07/02/2020 \\
\hline
\end{tabular}

\section{Abstract}

Balochistan has the largest rangeland area among other provinces of Pakistan. It is bestowed with large number of small ruminants, camel heads along with various ecological zones. These zones have different rangeland species that have varied feeding potential for livestock of the province. However, this feeding potential varies with season, growth and rainfall pattern in different zones and within zones. The scanty and scattered work has been done in different areas of Balochistan, however known feeding worth of these rangelands is still lacking at large scale. The key purpose of this manuscript is compile the scattered and scanty work on rangelands of Balochistan so that future research areas can be identified and policy for preventing degradation, sustainability and improvement in feeding value of rangelands can be planned.

Keywords: Balochistan; Feeding; Livestock; Nutrients; Rangelands

\section{Introduction}

The area of Pakistan is 88 million hectares. Of this total area, $65 \%$ is considered as rangelands. There are five major kinds of ecological range zones such as sub-tropical humid, tropical arid, sub-tropical sub humid, Mediterranean, sub-semiarid desert plain [1]. These rangelands are important source of feed for livestock population with variation in the precipitation about $125-1500 \mathrm{~mm}$ per annum. The rangeland areas of Pakistan are supporting about 30 million of the livestock herds that share about 400 million dollar with national income [2].

It is reported that rangelands having more ecological zones provides greater diversity of forage and hence results in higher livestock gains even during dry seasons [3]. In Balochistan province, the rangeland species varies with rainfall. It is estimated that approximately $80 \%$ animals of the province particularly sheep and camel species depends on rangelands. However, its feeding value varied. In its south, desert scrubs mostly seen, in the central area there is dominancy of shrub grassland of Haloxylon and Artemesia (sagebrush) species whilst in the north perennial grassland of Cymbopogon and Chrysopogon is found. Due to heavy grazing load, the already reported many native annual species have almost vanished $[4,5]$. Of total livestock heads in Pakistan, Balochistan possess $48,41,23,7$ and $1 \%$ of sheep, camels, goats, cattle and buffaloes, 
respectively $[6,7]$. Different ecological zones of Balochistan have different rangeland species. In this context, scanty and scattered work has been done in different areas of the province, however known feeding worth of these rangelands is lacking. Keeping in view these facts, the key purpose of this manuscript is to compile the scattered and scanty work on rangelands of Balochistan so that future research areas can be identified and policy for preventing degradation, sustainability and improvement in feeding value of rangelands can be effectively designed.

\section{Rangelands in Balochistan}

Rangelands are good source for grazing of livestock particularly sheep, goats and camels. It usually sustain maintenance requirement of these livestock depending upon the nutritional profile, rains, grazing pressure and likely other factors. Climate change and atmospheric nitrogen deposition are the other major reasons that have affected the rangeland types and their productivity [8]. In Balochistan, based on annual productivity, researchers have some worker divided rangelands of Balochistan into three major classes i.e., poor, medium and high potential areas based on annual productivity. They further elaborated that poor, medium and high productivity areas yield $50 \mathrm{~kg}, 60-190$ $\mathrm{kg}$ and $200-250 \mathrm{~kg}$ dry matter per hectare, respectively. The north zones are composed as better sites of rangeland of this province, which are situated in of the north region i.e., Khuzdar, Pishin, Quetta, Kalat, Zhob, Loraai, Nasirabad, Kohlu and Sibi districts of province. The above described zones are equal to $18 \%$ of all area of the province and carry $76.5 \%$ of livestock provincial population. The south zone of the province is considered as the poor zone for rangeland i.e., Lasbela, Turabat, Gawadar, Chagi, Kharan, Panjgur and remaining part of Khuzdar district that cover $62 \%$ of total area and $23.5 \%$ of the total population of livestock.
It is reported that approximately $93 \%$ area of Balochistan can be characterized as rangelands [9]. The rangelands of Balochistan also categorized in the context of property regimes as common and open rangelands [10]. The tribes traditionally own common rangelands which are open and free access for all. The area under open rangelands have been increasing due to the fact that more special common rangelands have been deteriorated to such an extent that their owners preferred to left their ownership. The rangelands also categorized on the basis of dry matter (DM) yield. The rangeland areas producing $250-280 \mathrm{~kg}$ DM per hector is excellent to very good; 200- $240 \mathrm{~kg} \mathrm{DM}$ per hector is very good to good; $170-190 \mathrm{~kg} \mathrm{DM}$ per hector is fair to good; $60-160 \mathrm{~kg} \mathrm{DM}$ per hector is poor to fair; $30-50 \mathrm{~kg}$ DM per hector is poor and below $30 \mathrm{~kg}$ DM per hector is categorized as non grazable [11].

Other researcher categorized rangeland of Balochistan in arid and semiarid zones depending based on the climate pattern [1]. They explained that production of rangeland in Balochistan province is significantly affected by absence of management practices regarding the grazing and fluctuation in the rain fall. These areas of rangelands are going to be decreasing very quickly in the relation as the production of biomass with favorable species of range. The deteriorating over grazing situation is getting visible everywhere. In this regard, many researcher have carried out studies to improve the yield and introduce new multi- beneficial verities. In a study, it was concluded that improvement in community rangelands is possible by involving all stakeholders and community through integrated approach in management of range livestock [12].

\section{Rangeland species in Balochistan}

Different grasslands contain diverse types of grasses, legumes, and other herbaceous species. Grasses provide the bulk feed. However, many forbs and some browse 
plants contribute positively in improving the feeding of animals. Rangeland species varies depending on climate, soil types, topography and biotic factors [13]. Shrub fodders are sharing an important part in the production of livestock in arid and semiarid zones of Balochistan [14]. These areas have benefit for the nutrition quality, palatability and production than other rangeland species. While documenting rangeland species, it was reported [15] that in dominant range grasses in highlands of Balochistan, are Cymbopogon jwarancusa (Jones) Schult and Chrysopogon aucheri (Boiss) Stapf, which are perennial in nature. Potential use of Atriplex canescens (Pursh) Nutt. which is commonly called four wing saltbush is also reported [16]. It is a perennial halophytic exotic shrub and has origin from Western United States. This shrub has shown performance as promising fodder shrub in highland area of Balochistan having 250-300 $\mathrm{mm}$ annual rainfall. In a study, it was explained that that Atriplex halimus L., A. nummularia Lindl., Medicago arborea L, Chamaecytisus proliferus Link subsp. palmensis (Christ.), G. Kunkel Colutea arborescens L., Gleditsiatria canthos L, Amorpha fruticosa L., Morusalba L., and Robinia pseudoacacia L. were nutritionally superior to most of the native species and hence recommended them for artificial plantation in the area in order to balance existing natural rangeland species [17].

Nutrients composition of rangeland species in Balochistan

It is evident from literature that the quality of forage depends on many factors i.e., the variation in year of season, pattern of rain fall, plant age, nature of soil and nature of chemical [18]. In general, many species of rangeland plant contain higher ratio of ash and fiber with low percentage of protein with medium detestability level. These plant have relatively small feeding values but they are not always same in their chemical composition as most species contain high contents of anti-nutritional chemicals i.e., saponins, tannins, alkaloids which limits utilization of nutrients and reduction in the production.

The crude protein contents in plant/rangeland species are important and have high value for animal feeding. Literature shows that actively growing forage contains more contents of crude protein (CP) as compared to dormant stage [17]. It is also reported that higher level of protein is a sign that crop was harvested from the fertile land or during the early stage of life. Commonly the percentage of protein content is high in the shurbs during the season of winter and rain fall as compared to other grass, but it has small amount of crude protein during the season of summer as well as spring [19]. The decline in CP content of the forage coupled with decreasing digestibility with age makes forages less nutritious as they mature. However, the $\mathrm{CP}$ in grasses decline more rapidly than in legumes [20].

The fiber contents of plant sources/rangeland species stand as essential part for assuming their quality. In plants and rangeland species, it is found that advancing plant maturity is accompanied by an increase in dry matter, which is reflected in the increase of cell wall contents, and a decrease in cell contents. The decline in organic matter digestibility of forages with plant age may be due to the increase in plants structural carbohydrates and lignin as reflected in an increased percentage of cell wall contents. The fiber content/cell wall contents can be calculated through ADF and NDF [21]. The primary composition of ADF is lignin and cellulose, whereas the composition of NDF is lignin, hemicelluloses and cellulose.

In relation to ash contents of plant source/rangeland species, it is reported that all minerals of plant can be recovered through ash contents by burning at $6000{ }^{\circ} \mathrm{C}$. The ash content provides sign for the presence of all 
mineral contents but can also make false indication about the higher values of nonnutritive factors or about silica [22]. There is no energy content in ash material. Large number of the plant which are halophytic have higher amount of ash content, in specific; when conditions are drought the ash content could increase from $18-30 \%$ to the total dry matter [23].

Various plant species differ in nutritional importance. Grasses, shrubs and trees are all playing important role in one or other way for the sustainability of livestock. The trees which serve as green fodder and shrubs are major sources of livestock feed. These both components maintain and support harsh environmental condition during the part of year for the animals. The share of shrub and tress is visible for fulfilling the need of animal. The tree fodder has large amount of minerals and $\mathrm{CP}$ which are major helper in the level of digestibility. The tree fodder are well known accepted by the livestock farmers due to their deep root system because they are producing continuously during the hot and dry season of the years. However, there are some anti nutritional component in few species which may cause problem for animal's health [24].

In a study on nutritional analysis of four wing saltbush, it was found that during mid-winter season, the crude protein content ranged from $12-15 \%$ in leaves [4]. Some scientists [12] introduced drought and cold-tolerant fodder shrub (Atriplex canescens) plantation. They recorded $140 \mathrm{~kg} / \mathrm{ha}, 174 \mathrm{~kg} / \mathrm{ha}$, and $190 \mathrm{~kg} / \mathrm{ha}$ in spring 2005, fall 2005 and spring 2006, respectively dry matter forage-production (above ground) at community-protected site. The dry matter forage production in open range area was $40 \mathrm{~kg} / \mathrm{ha}$ during spring 2006 . The work on some fodder species at three phenological stages in Harboi rangeland of Balochistan wwas carried out to know their proximate composition and cell wall components [25]. They found more dry matter (DM), nitrogen free extract (NFE), neutral detergent fiber, acid detergent fiber and hemicelluloses in grasses than shrubs. On the other hand, they found more ash, crude protein, ether extract (EE) and ADL contents in shrubs than grasses. Moreover, they concluded that chemical analysis varied with phonological stages and nutritional value decrease with advancement in phonological stage. They also deduced that carrying capacity of available grasses is less as compared to the nutritional requirement of small ruminants for maintenance and growth during all seasons. Likewise, in Harboi region of Kalat, Balochistan the concentration of nitrogen in Chrysopogon aucheri (Boiss) Stapf and Cymbopogon jwarancusa (Jones) Schult during different seasons was studied [15]. They recorded that nitrogen concentration in these rangeland plants varied from $12.4-13 \mathrm{mg}$ g-1 during spring, 15.4-17.26 mg g-1 during early summer and 6.7 to $10.7 \mathrm{mg}$ g-1 during late summer, respectively. They were of the view that after good rains the very long protected grasslands is adequate for heavy grazing for short time. In the earlier stated study [25] it is reported that DM contents in Pennisetum orientale, Stipa pennata, Cymbopogon jwarancusa and Tetrapogon villosus were 63.41, 69.04\%, 73.78 and 90.9\%, respectively. Among shrubs, the DM in Perovskia abrotanoides and Artemisia maritime were $52.23 \%$ and $71.7 \%$. The CP contents among grasses ranged from 6.83$9.95 \%$ in Pennisetum orientale and Cymbopogon jwarancusa. Whilst among shrubs it ranged from $8.23 \%-11.51 \%$ in Hertia intermedia and Artemisia maritime, respectively. ADF contents among grasses was maximum $(42.33 \%)$ in Pennisetum and minimum (35.4\%) in Tetrapogon. In a study conducted in Lasbela region, fifteen different rangeland species (Salvadora persica L, Prospis Juliflora, Suaeda fruticosa, Conolulus glomeratus Choisyin, Calotropis 
Procera, Prospis Juliflora, Cressa Cretica L, Sehoenus Nigricans L, Datura Alba Solanaceae, Taverniera Spartea, Abutilon Muticuin, Heliotropium Curassavicum, Prosopis Cineraria, Ziziphus Mauritiana and Cynodon Dactylon) grazed by small and large ruminants were chemically analysed [7]. He found variation in chemical composition and fiber contents. Among these rangeland species, $\mathrm{CP}$ contents as percent of dry matter was found maximum $(\mathrm{P}<0.05)$ in Sehoenus Nigricans L $(28.38 \pm 1.90)$ and Datura Alba Solanaceae (27.28 \pm 5.20$)$ and minimum $(\mathrm{P}<0.05)$ in Prospis Juliflora $(11.34 \pm 2.19)$. The EE contents $(\%)$ were found maximum in Prosopis Cineraria (4.49 \pm 1.24$)$ whilst Suaeda fruticosa showed least $(\mathrm{P}<0.05,0.97 \pm 0.58) \mathrm{EE}$ contents. The maximum $(\mathrm{P}<0.05)$ ash contents (33.20) recorded in Sehoenus Nigricans $L$ while the least $(\mathrm{P}<0.05)$ ash contents recorded in Cynoden Dactylon (4.38 \pm 2.55$)$. The NDF contents were highest $(\mathrm{P}<0.05)$ NDF in Datura Alba Solanaceae (55.21 \pm 3.22$)$ whilst lowest $(\mathrm{P}<0.05)$ in Salvadora persica $\mathrm{L}$ (25.66 \pm 3.39$)$. The ADF contents were maximum $(\mathrm{P}<0.05)$ in Datura Alba Solanaceae (29.22 \pm 2.90$)$, whilst minimum in

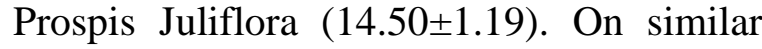
fashion, samples of nine different livestock preferred rangeland species (Koelpinia Linearis Pallas, Euphorbia Falcata, Tribulus Pentandrus, Launaea Glomerata, Cardaria draba, Rostraria cristate, Cenchrus Ciliaris, Isatis stocksii boiss, Melva Neglecta wallr, Atriplex Dimorposregium, Polypogon monspeliensis, Tamarix Articulata Vahl, Salsola Arbuscula Pallas) were collected from two different area of Kharan region in Balochistan [26]. Among these rangeland species, he found that highest $(\mathrm{P}<0.05) \mathrm{DM}$ contents were observed in Rostraria cristate (96.60 \pm 1.10$)$, whilst lowest $(\mathrm{P}<0.05) \mathrm{DM}$ contents recorded in Melva Neglecta wallr

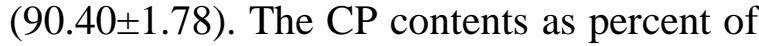
dry matter was found maximum $(\mathrm{P}<0.05)$ in
Salsola Arbuscula Pallas (30.60 \pm 5.19$)$ and minimum $(\mathrm{P}<0.05)$ in Melva Neglecta wallr (10.22 \pm 3.18$)$. The maximum $(\mathrm{P}<0.05) \mathrm{EE}$ contents $(\%)$ were found in Koelpinia Linearis Pallas $(3.87 \pm 1.11)$ whilst Melva Neglecta wallr showed least $(\mathrm{P}<0.05$, $1.50 \pm 0.33) \mathrm{EE}$ contents. The NDF and ADF contents were highest $(\mathrm{P}<0.05)$ in Salsola Arbuscula Pallas (59.33 $\pm 3.30 ; 42.19 \pm 6.11)$ whilst lowest $(\mathrm{P}<0.05)$ in Tribulus Pentandrus $\quad(29.89 \pm 7.88 ; \quad 18.89 \pm 6.76)$, respectively.

\section{Rangelands degradation in Balochistan}

The rangelands degradation occurs because of poor plans for grazing management and vegetation loss for the purpose of fuels in the form of wood. It happens due to lack of any visible administration for its ownership. Important indications for the degradation of rangeland are species shift, composition biodiversity, range losses with decrease in the production of biomass and low covering plant [27].

It has been observed that improper utilization/overgrazing by nomads, humaninduced stresses, drought and erosion are various causes of rangelands degradation in Balochistan. The rangeland degradation in Balochistan are particular and only depending on present grazing accessibility, vegetation pastures for grazing, population of human with water stock availability and conflict of tribes [28]. The palatable species of shrubs and perennial grass are only found in the few protective regions of forest. It is reported that large number of rangeland species are going to be replaced with low or unpalatable species of shrubs such Othonophasis intermedia and Peganum harmala due to visible erosion of soil [12].

\section{Conclusion and recommendations}

Balochistan owns major chunk of rangelands in Pakistan which are major source of feeding huge number of sheep and camels. The existing nutritional profile of rangelands differ among zones, seasons and rainfall 
pattern. In lieu of climate change and variation in rainfall and droughts, the studies on different aspects of rangeland management, palatability and consequent livestock feeding is need of the time. Studies on different aspects of rangelands in all ecological zones are scanty and limited. The initiation of mega research project addressing the carrying capacity of rangelands in all ecological zones, preferred rangeland species of small ruminant, large ruminants and wildlife, introducing livestock preferred exotic drought resistant varieties, rotational grazing and community awareness are different aspects to carry out studies, designing plans and executing policies in Balochistan.

\section{Authors' contributions}

Conceived and designed the review paper: IB Marghazani, Contributed in collection of reviews: M Yassen \& $\mathrm{M}$ Afzal, Analysis of collected reviews: I Kakar, SA Khoso \& IB Marghazani, Wrote the paper: IB Marghazani

\section{References}

1. Ahmad S, Afzal M, Jasra AW, Islam M., Aslam S. Ismail M \& Koukab S (2008). Rangeland improvement by community participation in high land Balochistan. Sci Vision 14: 59-66.

2. Anonymous (2006). Economic Survey. Govt. of Pakistan. Ministry of Finance, Islamabad.

3. Averi QR, Justin DD, David JA, Lauren MP \& María EF (2019). Ecological Sites: Can they be managed to promote livestock production. Rangelands 41(6): 239-243.

4. Thomson EF \& RodrIguez A (1994). Land and range resource management issues and food security in Balochistan. International Center for Agricultural Research in the Dry Areas, Aleppo, Syria.

5. Foroughbakhch JL, Hernandez PA, Carrillo P \& Rocha EA (2013). Composition and animal perferance for plant used for goat feeding in semi-arid northeastern Mexico. J. of Plant and Animal Sci 23(4): 1034-1040.

6. Marghazani IB, Kakar MH, Umar M., Luni FA, Saleem M, Hamayoon K \& Safi JM (2019). The Camels in Balochistan: Status, farming practices and camel centered measures. Pure and Appl Biol 8(1): 503-508.

7. Yaseen M (2017). Identification and nutritional profile of rangeland species (grasses, herbs, shrubs, trees) grazed by small and large ruminants in Lasbela region. M. Phil Thesis. Department of Animal Nutrition, Sind Agriculture University, Tandojam.

8. Kaihui L, Xuejun L, Yukun H, Anwar M, Fengzhan G \& Wenxuan H (2020). Long term increasing productivity of high elevation grassland caused by elevated precipitation and temperature. Rangeland Ecol and Manage 73(2000): 156-161.

9. FAO (1983). Food and Agriculture Organization 1983. Report: Balochistan assistance to rangelands and livestock development. TCP/ PAK/0107. FAO. Tech. Coop. Prog., FAO, Pakistan.

10. Buzdar N, Nagy JG, Sablr GF \& Keatlnge JDH (1989). Animal raising in highland Balochistan: a socio-economic perspective. MART/AZR Project Research Report 50, ICARDA, Quetta.

11. IUCN (2005-2006). International Union for Conversation of Nature Report: Balochistan Conversation Strategy, IUCN, Balochistan, Quetta.

12. Ahmed S, Islam M, Sarwat N \& Mirza M (2012). Rangeland degredation and management and management approaches in Balochistan, Pakistan. Pak J Bot 44: 127-136.

13. AOAC (2000). Association of Official Analytical Chemists. Official Methods of Analysis, $17^{\text {th }}$ ed., Washington, DC, USA. 
14. Mohammad N (1989). Rangeland management in Pakistan. Publisher; The International Center for Integrated Mountain Development.

15. Bano G, Islam M, Ahmad S, Aslam S \& Koukab S (2009). Seasonal variation in nutritive value of Chrysopogon aucheri (Boiss) stapf, and Cymbopogon jwarancusa (Jones) schult, in highland Balochistan, Pakistan. Pak J Bot 41(2): 511-517.

16. Mirza SN, Akbar G \& Begum I (1995). Land degradation and its control in highland Balochistan. Progressive Farming 15(2): 46-51.

17. Shenkute B, Hassen A, Assafa T, Amen N \& Ebro A (2012). Identification and nutritive values of potential fodder trees and shurbs in mid rift valley of Ethopia. $J$ of Plant and Animal Sci 22(4): 11261132.

18. Abule E (2003). Rangeland evaluation in relation to pastoralists' perceptions in the Middle Awash Valley of Ethiopia. PhD thesis submitted to the University of the Free State, Bloemfontein, South Africa, pp 297.

19. Mehramiz MR (1998). Nutrient contents of three atriplex species atriplex cancensces atriplex linearis and atriplex polycarpa under different management practices and site conditions atriplex. PhD. Thesis, University of Arizona USA.

20. Van Soest PJ (1994). Nutritional Ecology of the Ruminant: Ruminant Metabolism; Nutritional Strategies, the cellulolytic fermentation and the chemistry of forage and plant fibres. Downey Inc., Durhamand, pp 25.
21. Weiss F (1991). Testing forage. What forage testing mean. Dairy Herd Workshop, pp 20-24.

22. Sullivan JT (1962). Evaluation of forage crops by chemical analysis. A Critique. Agron J 20, PSll-S1S.

23. Gilhad EA \& Shaer HM (1994). Utilization of halophytes by livestock on rangelands problem and prospects. Halophytes as a resource for livestock and for rehabilitation of degraded lands, Kluwer Academic Publishers, pp 77-96.

24. Atiya A, Shakira G, Asma L \& Mukhtar AN (2011). Nutritional evaluation of some top fodder tree leaves and shrubs of district Chakwal, Pakistan in relation to ruminants requirements. Pak J of Nutr 10(1): 54-59.

25. Hussain F \& Durrani MJ (2009). Nutritional evaluation of some forage plants from Harboi rangeland, Kalat, Pakistan. Pak J Bot 41(3): 1137-1154.

26. Afzal M (2017). Identification and nutrients composition of rangeland species (grasses, herbs, shrubs, trees) grazed by small and large ruminants in Kharan region. M.Phil Thesis. Department of Animal Nutrition, Sind Agriculture University, Tandojam.

27. Ahmad SS \& Ehsan H (2012). Analyzing the herbaceous flora of Lohi Bher Wildlife Park under variable environmental stress. Pak J Bot 44(1): 11-14.

28. Ahmad S \& Islam M (2005). Assessment of nutritional potential and performance of range species in Balochistan. ALP Project Report. Arid Zone Research Centre, Quetta. 